\title{
Digestibility, Digestible and Metabolizable Energy of Earthworm Meal (Eisenia Foetida) Included in Two Levels in Guinea Pigs (Cavia Porcellus)
}

\author{
Jorge Castro-Bedriñana*,1, Doris Chirinos-Peinado ${ }^{1}$, Hanz Sosa-Blas² \\ ${ }^{1}$ Faculty of Zootechnics, Universidad Nacional del Centro del Perú. Huancayo, 12000, Perú \\ ${ }^{2}$ FONCODES - Technical advisor - Chanchamayo, 12840, Perú
}

\section{A R T I C L E I N F O}

Article history:

Received: 05 April, 2020

Accepted: 05 May, 2020

Online: 15 May, 2020

Keywords:

Food nutritional value

Total digestible nutrients

Voluntary food intake

Gross energy

Digestibility assays

Digestibility coefficients

Animal protein production

Proximal chemical analysis

Metabolic cages

\begin{abstract}
A B S T R A C T
The increasing cost of fishmeal and soybean meal forces us to look for unconventional sources of protein to feed guinea pigs, being able to use earthworm meal Eisenia foetida (EF) with 60-80\% high quality raw protein; for this, the contribution of digestible nutrients and metabolizable energy must be known to formulate rations. The objective is to evaluate the nutritional quality of EF used in 10 and $20 \%$ in guinea pig diets. The research procedure considered the preparation of EF, proximal chemical analysis, digestibility tests "in vivo" by the direct method for the reference diet of barley meal (BM) and indirect tests for EF, using 5-month-old male guinea pigs and homogeneous weights (700-750 g), placed in individual metabolic cages and randomly distributed in 3 groups of 3 animals per group, (G1): Reference diet (BM), (G2): EF 10\% + 90\% BM and (G3): EF 20\% + 80\% BM. To determine the mean difference of digestibility, total digestible nutrients (TDN), digestible energy (DE) and metabolizable energy (ME) between G2 and G3. The average content of dry matter, crude protein, fat, nitrogen-free extract and organic matter of the EF was 77.16, 66.90, 10.0, 21.1 and $91.0 \%$, and the average digestibility coefficients of these components were 68.01, 92.96, 72.40, 41.34 and 71.68\%; the ME content was $3125.31 \mathrm{Kcal} / \mathrm{kg}$. As the EF level increased from 10 to $20 \%$, the digestibility coefficients of dry matter, protein, fat, nitrogenfree extract and organic matter increased by $7.75 ; 2.18 ; 5.45 ; 16.20$ and $4.83 \%$, the ME value increased by $7.25 \%(P<0.05)$. Increasing the inclusion of EF from 10 to $20 \%$ in guinea pig diets improves digestibility nutrients and $M E$ content. Reduction in the cost of animal protein production, added value for the cultivation of Eisenia foetida and contribution to environmental health.
\end{abstract}

\section{Introduction}

The guinea pig, originally from the Andes Mountains of Peru, Colombia, Ecuador and Bolivia, due to its nutritional quality and healthy properties, is important in the nutritional food security of the Andean population [1,2].

The high protein content (21.4\%), B vitamins (15 mg / $100 \mathrm{~g})$, low cholesterol (65 mg / $100 \mathrm{~g}$ ), low saturated fat (3\%), low sodium, linoleic and linolenic acid presence (absent or low concentration in other meats) qualify guinea pig meat as a healthy food for any population group [3,4].

${ }^{*}$ Corresponding Author. Jorge Castro-Bedriñana, Av. Mariscal Castilla No 3909

El Tambo, Huancayo. Perú. +51 964408057 \& : jorgecastrobe@yahoo.com
According to estimates of the Cámara Peruana del Cuy [5], about 18 million guinea pigs are raised in Peru, 50\% more compared to the IV National Agricultural Census of 2012, and national and international demand requires guinea pigs of a standard size and quality. Exports went from two tons in 2002 to twenty in 2015; United States is the main destination.

This productive level demands rapid growth, better rates of food conversion and higher yield of guinea pig meat, using diets of high nutritional value; but, if conventional protein foods (fish meal or soybean meal) are included, production costs are raised, and unconventional protein sources such as California redworm meal Eisenia foetida should be evaluated [6].

The earthworm meal Eisenia foetida (EF) contains $18.6 \%$ dry matter and depending on the processing, a dry basis it contains 60 - 
$80 \%$ low-cost crude protein [7]-[9], $1.3 \%$ crude fiber (CF); 7-10\% fat, $8-20 \%$ nitrogen free extract, 3-6\% ash, and $4000 \mathrm{kcal} / \mathrm{kg}$ gross energy [10]. Essential amino acids outperforms to the fishmeal and soybean meal, and contains lysine (2.7-6.8\%), methionine (0.76$1.2 \%)$, phenylalanin (1.8-3.5\%), leucine (3.1-5.0\%), tryptophane (0.12-1.73\%), threonine (1.8-5.2\%), histidine (1.4-2.6\%), arginine (2.8-4.4\%), valine (1.3-4.7\%), isoleucine (1.2-6.2\%) among others [11-15]. EF also contains niacin, riboflavin, thiamine, pantothenic acid, pyridoxin, cyanocobalamin, folic acid, being considered as a biotechnological resource of high nutritional and ecological interest of some developing countries $[9,15]$, and by its pleasant smell and good palatability [16] can be included in animal and human diets $[8,9]$.

The EF can use manure of pigs, guinea pigs, rabbits, poultry, sheep and cattle as substrates, combined with organic and agricultural waste, which are commonly thrown away and are a source of contamination $[7,11,17,18]$. The EF adapts to a wide range of soil and climate conditions, and reproduces better when the substrate temperature is between 14 and $27^{\circ} \mathrm{C}$, being the optimum $21{ }^{\circ} \mathrm{C}$, but can survive between $0-42{ }^{\circ} \mathrm{C}[9]$.

In the vermicompost, different organic materials are transformed into useful products for humans, such as organic fertilizers (with multiple benefits for agriculture) [19], earthworm meat, earthworm meal, earthworm tea, cookies, cakes, among others [20], obtaining $100 \%$ natural and organic products. The EF is a powerful natural anabolic and because of the rapid absorption of amino acids, the immune system does not recognize them as foreign elements, as with other proteins of animal origin that are rejected by the immune system [14].

The research objective is to evaluate the nutritional quality of Eisenia foetida worm meal (Figure 1) for guinea pigs, included in 10 and $20 \%$ to diets based on ground barley, through proximal chemical analysis, digestibility tests and digestible and metabolizable energy estimation.

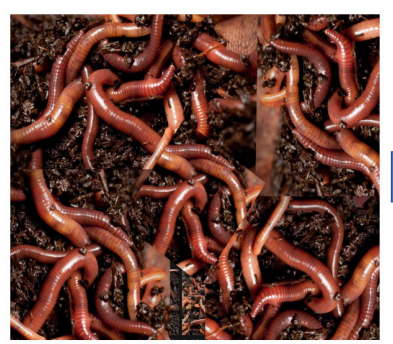

Eisenia foetida

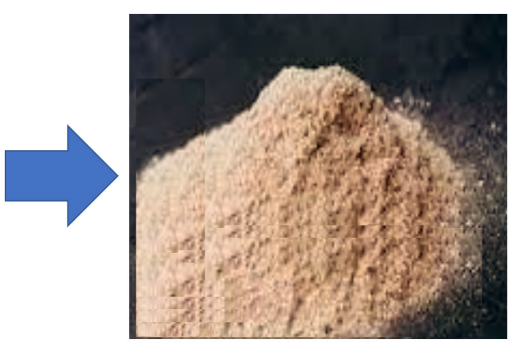

Earthworm meal (Eisenia foetida)
Figure 1. Eisenia foetida and earthworm meal

\section{Materials and methods}

\subsection{Site Study}

The research was conducted in the Digestibility Room of the "Yauris" Agricultural Farm of the Universidad Nacional del Centro del Perú (UNCP), Huancayo-Junín, altitude 3253, at $12^{\circ}$ 03 ' $14^{\prime}$ 'SL and $75^{\circ} 12^{\prime} 55^{\prime}$ 'WL. The proximal analyzes were carried out in the Animal Nutrition Laboratory, Faculty of Zootechnics-UNCP.

The digestibility room was well ventilated and illuminated. All procedures related to the handling and treatment of animals followed the ethical standards of animal welfare in research, and the care and use of laboratory animals. After the study, the guinea pigs returned to their breeding system.

\subsection{Experimental samples}

For digestibility tests, nine 5-month-old male guinea pigs of the Wanka breed were used, of similar weights $(700 \mathrm{~g})$, in good health and distributed in three groups of three guinea pigs each, randomly arranged in individual metabolic cages.

The number of animals per group responds to international recommendations for the care and use of research animals, which suggest minimizing the number of animals used [21, 22].

The process followed in the investigation is summarized in seven phases (Figure. 2).

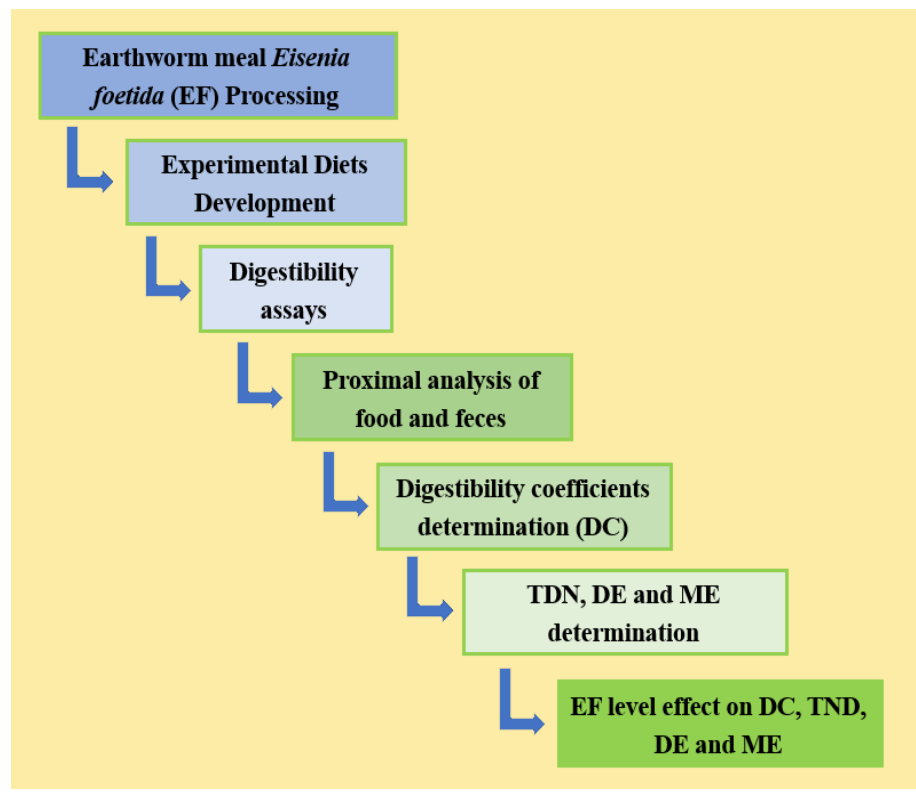

Figure 2. Sequence of the investigation procedure

\subsection{Earthworm meal Eisenia foetida (EF) manufacturing process}

Eisenia foetida is a product of the vermicomposting; process involving mutual action of earthworm and microorganisms to transform biodegradable organic matter to humus-like vermicast and vermiliquid [23]; thus, the symbiotic activity of the microorganisms contributes to improving the quality of the products and increases their nutritional value [24].

Earthworms were fed a diet of organic waste compost twice a week specifically forage residues and guinea pig manure, that are high in organic matter and readily available, as suggested by $[11,17,18]$; manure is the most preferred by earthworms, and providing organic matter, it stimulates biodegradation and raises $\mathrm{pH}$ within the culture substrate.

The feed was spread on top of compost and water was sprinkle on it and then feed was thoroughly mixed with compost. In order to guarantee optimum growth conditions, optimum temperature 12$24^{\circ} \mathrm{C}$, moisture $80-90 \%$ and $<5 \mathrm{pH}<9$ of the compost was kept under control [25]. 


\section{J. Castro et al. / Advances in Science, Technology and Engineering Systems Journal Vol. 5, No. 3, 171-177 (2020)}

$20 \mathrm{~kg}$ of earthworms Eisenia foetida were used to make $2.6 \mathrm{~kg}$ of meal (13\% yield). The worms were placed in a bowl for $3 \mathrm{~h}$ to evacuate the intestinal contents [26], washed with clean water and placed in a hot $4 \%$ salt solution for 10 minutes [27], rinsed and dried in an oven at $90^{\circ} \mathrm{C}$. ${ }^{\circ} \mathrm{C}$ for $6 \mathrm{~h} \mathrm{[28];} \mathrm{then,} \mathrm{they} \mathrm{were} \mathrm{cooled,} \mathrm{ground} \mathrm{and} \mathrm{sieved} \mathrm{on} \mathrm{a}$ 60 mesh, obtaining a light brown flour. The EF was packaged in clean, dry plastic bags with an airtight seal to prevent excess moisture and attack by fungi or other pathogens that rapidly contaminate and degrade [9].

\subsection{Study diets and pre-experimental stage of the digestibility assays}

At the beginning of the pre-experimental phase all animals received $300 \mathrm{~g}$ / day of Lolium multiflorum, gradually replaced by the experimental diets and drinking water + vitamin C "ad libitum", in nipple drinking fountains (Figure 3), until the fifteenth day they exclusively consumed the study diets.

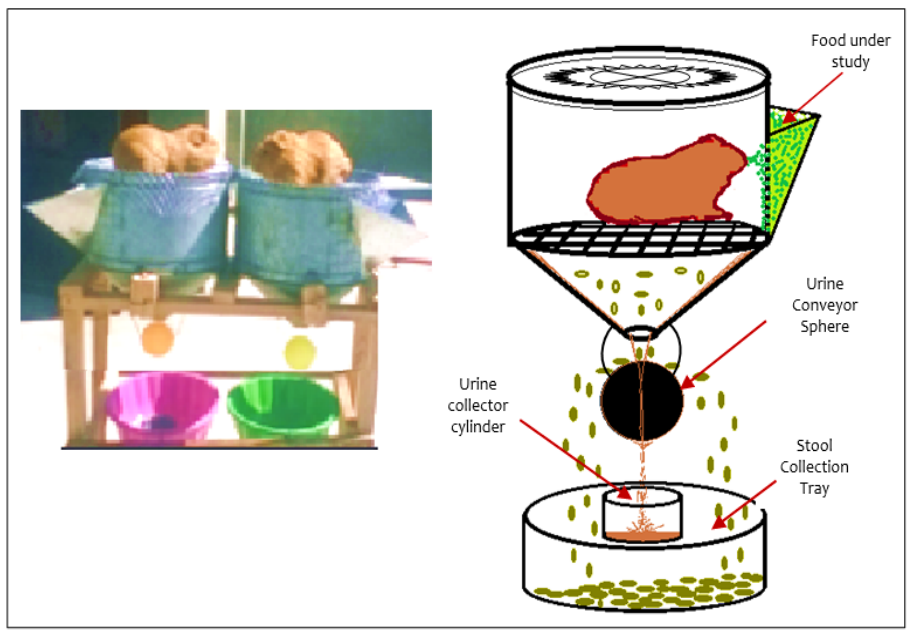

Figure 3. Metabolic cage for guinea pigs (Granja Agropecuaria de Yauris UNCP). Fuente: [29]

Digestibility tests were performed for three diets:

(D1): Reference diet (100\% barley meal)

(D2): $10 \% \mathrm{FE}+90 \%$ reference diet

(D3): $20 \% \mathrm{EF}+80 \%$ reference diet

For D1, digestibility was determined by the direct "in vivo" method, assuming that the indigestibility of barley flour (BM) is the same when combined with EF. And from their indigestion coefficients, subsequent calculations are performed to determine the digestibility of EF by the indirect method [29,30].

\subsection{Experimental stage and chemical analysis}

The experimental phase considered the exact measurement of consumption and individual production of guinea pig feces, assuming that feces collected on a given day correspond to the indigestible food consumed the previous day. This stage had a period of seven days.
The study diets and their corresponding feces were taken to the stove to determine the dry matter content, then were ground, homogenized and taken to the laboratory.

To determine the chemical composition of BM, EF, and Guinea pig feces, the proximal analysis was used, following the AOAC protocols [31]. The proximal analysis considered crude protein ( $\mathrm{N} \times 6.25)$, ether extract, crude fiber, ash and nitrogen free extract.

The TDN content, which describes the energy available in food [32] was calculated from the digestibility tests [33,34].

The values of $\mathrm{DE}$ and ME were estimated with validated equations. DE content was estimated from the TDN concentration, it was considered that one $\mathrm{kg}$ of TDN is equivalent to $4,400 \mathrm{Kcal}$ of $\mathrm{DE}$ [35-37]. The ME content was corresponded to the average of two estimates, the first where, $\mathrm{ME}=\mathrm{DE} * 0.82$ [36-40], and the second, where, $1 \mathrm{~kg}$ TDN $=3,560 \mathrm{kcal} / \mathrm{kg} \mathrm{ME}$ [41].

\subsection{Statistical analysis}

The level of statistical significance was set at $\mathrm{P}<0.05$, and all analyses were two-sided. The digestibility coefficients, TDN, DE, and $\mathrm{ME}$ of EF used in 10 and $20 \%$, were compared by means of a " $t$ " test for the difference of independent means, using SPSS 23. Intake data were expressed as quantity of diet consumed (in grams) per day per animal, and as percentage of live weight [42].

\section{Results}

\subsection{Chemical composition of barley meal (BM) and earthworm meal (EF)}

The proximal chemical composition of BM and EF used in the digestibility tests (Table 1) is within the range found in other studies [43]. The analyzes of each food sample were in triplicate.

Table 1. Proximal chemical composition of barley meal and earthworm meal

\begin{tabular}{lcccccccc}
\hline \multicolumn{1}{c}{ Food } & M & DM & CP & EE & CF & NFE & A & OM \\
\hline $\begin{array}{l}\text { Barley meal } \\
(\mathrm{BM})\end{array}$ & 11.38 & 88.63 & 11.81 & 3.50 & 6.10 & 76.6 & 2.0 & 98.0 \\
$\begin{array}{l}\text { Earthworm meal } \\
(\mathrm{EF})\end{array}$ & 22.84 & 77.16 & 66.90 & 10.00 & 0.00 & 14.1 & 9.0 & 91.0 \\
\hline
\end{tabular}

Averages of all the components of the BM and EF were highly significant $(\mathrm{P}<0.01)$.

M: Moisture, DM: Dry matter, CP: Crude protein, EE: Ether extract, CF: Crude fiber, NFE: Nitrogen free extract, A: Ash, OM: Organic matter.

Unit: Percentage

$\mathrm{BM}$ has been used as a reference diet in digestibility tests by the indirect method, and generally constitutes $90 \%$ of the diet with $10 \%$ of the ingredient under study [29].

The crude protein and fat content of the EF found in this study is similar to that reported by [43] $66.2 \%$.

The crude protein and fat content of EF was similar to the reports by [44]. Other studies reported lipid contents on dry 
matter of EF were 7.34\% [12], 11.3\% [27], 6.6\% [45] and 18\% [46].

\subsection{Digestibility of barley meal (BM)}

The digestibility coefficients of the BM components (Table 2), were used to determine the digestibility of EF by the indirect method [29].

Table 2. Digestibility coefficients and total digestible nutrients of barley meal

\begin{tabular}{lcccccc}
$\begin{array}{c}\text { Digestibility coefficient } \\
(\%)\end{array}$ & N & Min & Max & Mean & SD & $\begin{array}{c}\text { Variance } \\
(\%)\end{array}$ \\
\hline Dry matter & 3 & 81.9 & 85.53 & 83.75 & 1.82 & 3.30 \\
Crude protein & 3 & 58.56 & 67.28 & 62.56 & 4.40 & 19.40 \\
Ether extract & 3 & 63.8 & 79.33 & 71.81 & 7.78 & 60.47 \\
Crude fiber & 3 & 75.37 & 78.65 & 77.26 & 1.70 & 2.87 \\
Nitrogen free extract & 3 & 86.15 & 89.17 & 87.69 & 1.51 & 2.28 \\
Organic matter & 3 & 83.2 & 86.41 & 84.92 & 1.62 & 2.62 \\
Total Digestible Nutrients & 3 & 83.06 & 87.29 & 84.92 & 2.16 & 4.66 \\
& & & & & & \\
\hline
\end{tabular}

The digestibility of crude protein from BM determined in this study is similar to that reported in other studies in which barley flour was used as a reference diet in digestibility trials in guinea pigs [29]; also, was similar to that observed in growing pigs [47].

\subsection{Digestibility, TDN, DE and ME of earthworm meal with 10 and $20 \%$ inclusion}

The digestibility coefficients of the EF were higher when entering the diet in $20 \%$ than with $10 \%$ (Tables 3 and 4 ).

Table 3. Digestibility coefficients and total digestible nutrient of the earthworm meal included in $10 \%$

\begin{tabular}{lcccccr}
\hline $\begin{array}{c}\text { Digestibility coefficient } \\
(\%)\end{array}$ & N & Min & Max & Mean & SD & $\begin{array}{c}\text { Variance } \\
\mathbf{( \% )}\end{array}$ \\
\hline Dry matter & 3 & 59.78 & 70.45 & 64.14 & 5.60 & 31.33 \\
Crude protein & 3 & 89.90 & 93.57 & 91.87 & 1.85 & 3.42 \\
Ether extract & 3 & 63.72 & 77.07 & 69.67 & 6.79 & 46.13 \\
Nitrogen free extract & 3 & 23.51 & 45.14 & 33.24 & 10.98 & 120.51 \\
Organic matter & 3 & 61.97 & 74.69 & 69.26 & 6.56 & 43.04 \\
Total digestible nutrients & 3 & 82.91 & 85.50 & 84.15 & 1.30 & 1.69 \\
\hline
\end{tabular}

Table 4. Digestibility coefficients and total digestible nutrients of earthworm meal included in $20 \%$

\begin{tabular}{lcccccc}
\hline $\begin{array}{l}\text { Digestibility coefficient } \\
(\%)\end{array}$ & N & Min & Max & Mean & SD & $\begin{array}{c}\text { Variance } \\
\text { (\%) }\end{array}$ \\
\hline Dry matter & 3 & 71.23 & 72.29 & 71.88 & 0.57 & 0.33 \\
Crude protein & 3 & 91.87 & 97.77 & 94.05 & 3.24 & 10.48 \\
Ether extract & 3 & 68.43 & 83.27 & 75.12 & 7.53 & 56.64 \\
Nitrogen free extract & 3 & 39.92 & 54.80 & 49.43 & 8.26 & 68.25 \\
Organic matter & 3 & 72.32 & 75.46 & 74.09 & 1.61 & 2.59 \\
Total digestible nutrients & 3 & 88.59 & 91.76 & 90.25 & 1.59 & 2.53 \\
\hline
\end{tabular}

$\underline{\text { www.astesj.com }}$
In the practical feeding of guinea pigs, depending of $\mathrm{EF}$ percentage in the diets, the digestibility coefficients determined in this study could be used (Figure 4).

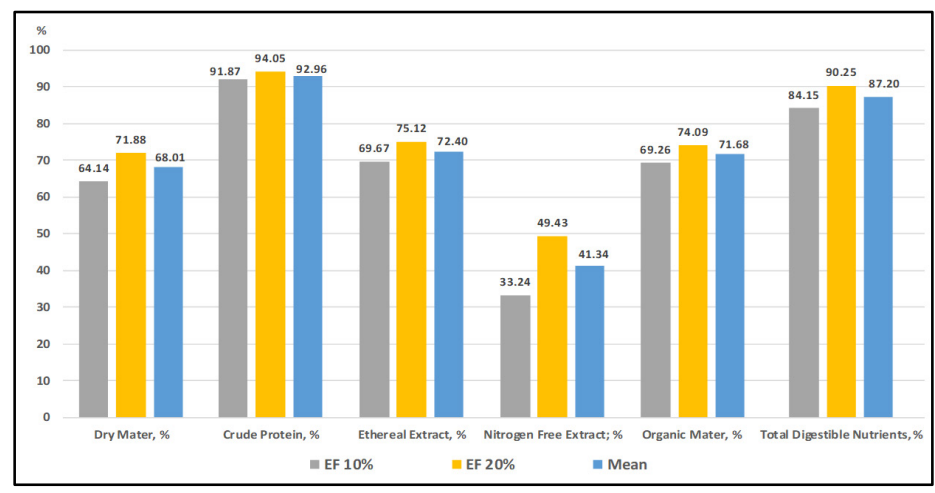

Figure 4. Digestibility coefficients and total digestible nutrient content of earthworm meal included in two levels

The results of the " $t$ " tests for the difference of means of samples independent of the digestibility coefficients, TDN, DE and ME of EF included in 10 and 20\%, show that the inclusion of $20 \%$ of EF significantly improves the availability of EF energy (Tables 5 and 6).

Table 5. "T" tests for the digestibility coefficients and TDN content of the earthworm meal included in 10 and $20 \%$

\begin{tabular}{lccc}
\hline Components & T test & p-value & Sig \\
\hline Dry mater & -2.397 & 0.075 & $\mathrm{~ns}$ \\
Crude protein & -1.015 & 0.367 & $\mathrm{~ns}$ \\
Ether extract & -0.929 & 0.405 & $\mathrm{~ns}$ \\
Nitrogen free extract & -2.036 & 0.111 & $\mathrm{~ns}$ \\
Organic material & -1.247 & 0.281 & $\mathrm{~ns}$ \\
Total digestible nutrients & -4.961 & 0.008 & $*$ \\
\hline
\end{tabular}

* Statistical difference $(\mathrm{P}<0.05)$.

ns: No statistical difference $(\mathrm{P}>0.05)$

When EF inclusion increased from $10 \%$ to $20 \%$, EF's DE and ME contribution increased by $7.25 \%$ (Figure 5).

Table 6. "T" test for the digestible and metabolizable energy of earthworm meal included in $10 \%$ and $20 \%$
Energy value
N Mean
SD

\begin{tabular}{llll}
\hline Digestible energy, HL 10\% & 3 & $3702.60 \mathrm{~b}$ & 57.13 \\
Digestible energy, HL 20\% & 3 & $3971.15 \mathrm{a}$ & 69.99 \\
Metabolizable energy, 10\% HL & 3 & $3015.93 \mathrm{~b}$ & 46.54 \\
Metabolizable energy, HL 20\% & 3 & $3234.68 \mathrm{a}$ & 57.01 \\
\hline
\end{tabular}

$\mathrm{a}, \mathrm{b}$, Average values of digestible and metabolizable energy with different letters vary statistically $(\mathrm{P}<0.05)$

\subsection{Earthworm meal Eisenia foetida consumption by guinea pigs}

When EF $10 \%$ was used, the daily fresh consumption per animal per day was $1.78 \mathrm{~g}$, equivalent to $1.37 \mathrm{~g}$ of dry matter and 


\section{J. Castro et al. / Advances in Science, Technology and Engineering Systems Journal Vol. 5, No. 3, 171-177 (2020)}

$0.21 \%$ of live weight; while when using $20 \%$, fresh consumption per animal per day was $4.36 \mathrm{~g}$, equivalent to $3.37 \mathrm{~g}$ of dry matter and $0.47 \%$ of live weight (Table 7 ).

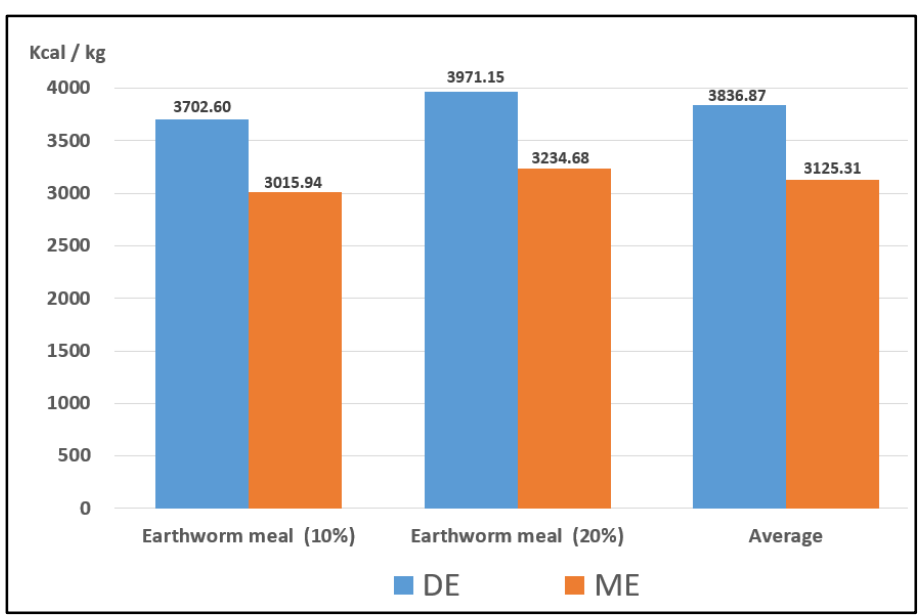

Figure 5. Digestible and metabolizable energy content of worm meal, included in 10 and $20 \%$

Table 7. Average consumption of earthworm meal per animal per day

\begin{tabular}{llll}
\hline & Evaluated diets & Mean & SD \\
\hline $\begin{array}{llll}\text { Average consumption / animal / } \\
\text { day, fresh base, g }\end{array}$ & EF (10\%) & $1,78 \mathrm{~b}$ & 0,020 \\
Average consumption / animal / & EF (20\%) & $4,36 \mathrm{a}$ & 0,313 \\
day, dry basis, g & EF (10\%) & $1,37 \mathrm{~b}$ & 0,015 \\
Average consumption / animal / & EF (10\%) & $3,37 \mathrm{a}$ & 0,241 \\
day, live weight \% & EF (20\%) & $0,21 \mathrm{~b}$ & 0,021 \\
\hline
\end{tabular}

Average consumption in fresh, dry basis and as live weight percentage by inclusion levels, with different letters vary statistically $(\mathrm{P}<0.05)$.

EF: Earthworm meal (Eisenia foetida)

Average consumption in fresh, dry basis and as live weight percentage by inclusion levels, with different letters vary statistically $(P<0.05)$.

\section{Discussion}

Although the statistical analysis does not show significant differences $(P>0.05)$ between the digestibility coefficients of dry matter, crude protein, ether extract, nitrogen free extract, and organic matter, when 10 and $20 \%$ of EF was used; with $20 \%$ of EF the digestibility coefficients were $7.75,2.18,5.45,16.20$ and $4.83 \%$ higher than with $10 \%$.

Inclusion $20 \%$ of EF allowed a higher content of TDN than when included in $10 \%(P<0.05)$. The TDN content was improved by $5.6 \%$ (82.91 to 88.59$)$; Similarly, digestible and metabolizable energy were higher when $20 \%$ of EF was used $(P$ $<0.05)$.

The improvement in digestibility and energy content of EF is due to the greater contribution of proteins and essential amino acids $[11,18]$ by using $20 \% \mathrm{EF}$, which increases the consumption, digestion and absorption of nutrients; similar result was observed when using 15\% EF [44], which reports digestibility coefficients of dry matter, protein, fat, nitrogen free extract and organic matter of $65.23,89.97,68.36,37.45$ and $70.08 \%$.

Digestibility coefficients are not constant for a given food and are influenced by many factors, including chemical composition, protein and amino acids levels. When dietary protein increases, the digestibility of the whole diet increases [29].

Digestibility of a food mixture is not necessarily the average of the values of its components determined separately; each food can influence the digestibility of others [29, 30].

When the inclusion of EF raised from $10 \%$ to $20 \%$, the DE and ME contribution of EF increased by $7.25 \%$ (3702.60 to 3971.15 and 3015.94 to $3234 \mathrm{kcal} / \mathrm{kg}$ ); In this regard [9] reports more than $95 \%$ digestibility of Californian red worm flour, which allows high nutrient absorption and high energy contribution.

When the inclusion of EF raised from $10 \%$ to $20 \%$, the consumption of EF increased by 2.45 times, which could have been due to the greater contribution of proteins and other nutrients; when the chemical composition of the diet is improved, it also improves digestibility and consumption [29, 39].

Another study on the digestibility of EF-71.2\% CP, in weaned guinea pigs, included in $15 \%$, reports digestibility coefficients for MS, PT, EE, ELN, MO of 65.23, 89.97, 68.36, 37.45 and $70.08 \%$, and when was included in $20 \%$, the coefficients were $69.87,92.09,72.55,43.89$ and $73.01 \%$, the higher level of inclusion improves the absorption of nutrients [44].

A recent study indicates that the inclusion of the EF in the proportions $(85: 15)$ in animal diets increased $(\mathrm{P}<0.05)$ the $\mathrm{CP}$, $\mathrm{EE}$, and A, mainly when mixed with rice powder, corn meal and soy cake meal [48].

Our results indicate the EF is among the non-conventional protein sources, with promising results, thanks to its high protein levels, proper amino acid profile, high reproduction rate, low mortalities, fast growth and ease of production [6].

Studies have shown that EF has recommendable levels of protein, essential amino acids and lipids, which are similar to those found in fishmeal and, are in line with the nutritional requirements of many species [11,18], and for its high biological value, is a possible solution to nutritional problems that humanity has. The richness and quality of amino acids and vitamin contribution of EF, not only satisfies the requirements of monogastric animals, but also of children between 2-5 years recommended by $\mathrm{FAO} / \mathrm{WHO}$; being a biotechnological resource of high nutritional and ecological interest [9].

\section{Conclusion}

Earthworm meal (Eisenia foetida) has a high nutritional quality for guinea pigs, significantly increasing its digestibility, energy value and consumption when included in the reference diet by $20 \%$ compared to $10 \%$.

The digestible and metabolizable energy content of earthworm meal included by $20 \%$ increased by $6.76 \%$ compared to $10 \%$. 


\section{J. Castro et al. / Advances in Science, Technology and Engineering Systems Journal Vol. 5, No. 3, 171-177 (2020)}

Due to the high content of digestible nutrients and metabolizable energy, earthworm flour could be included in $20 \%$ of guinea pig diets.

\section{Conflict of Interest}

The authors declare no conflict of interest.

\section{Acknowledgment}

To the Guinea Pig Program of the Yauris Agricultural Farm, Universidad Nacional del Centro del Perú, for the facilities provided in the breeding and processing of earthworm meal and digestibility tests. This research did not receive any specific funding.

\section{References}

[1] Avilés DF, Martínez AM, Landi V, Delgado JV. El cuy (Cavia porcellus) un recurso andino de interés agroalimentario. Animal Genetic Resources, 55, 87-91, 2014. https://doi.org/10.1017/s2078633614000368.

[2] Chirinos D. Seguridad alimentaria nutricional en poblaciones vulnerables de la región central del país. Primera edición. Gráfica JOSIMPRESORES SAC. Huancayo. Perú. 2016.

[3] Zumárraga S. Innovaciones gastronómicas del cuy en la provincia de Imbabura. Universidad Técnica del Norte (UTN), Ecuador. 2011. http://repositorio.utn.edu.ec/bitstream/123456789/1139/2/06\%20GAS\%200 14\%20TESIS.pdf

[4] Crespo N. La Carne de Cuy: Nuevas propuestas para su uso. Tesis Gastronomía y Servicio de Alimentos y Bebidas. Universidad de Cuenca. Ecuador. 2012. https://dspace.ucuenca.edu.ec/bitstream/123456789/1563/1/tgas26.pdf.

[5] AAN. Producción de cuy en Perú creció 50\% en los últimos cinco años. Agencia agraria. Grupo Camposur. 2016. Available: https://agraria.pe/noticias/produccion-de-cuy-en-peru-crecio-50-12352.

[6] Musyoka SN, Liti DM, Ogello E, Waidbacher H. Utilization of the earthworm, Eisenia foetida (Savigny, 1826) as an alternative protein source in fish feeds processing: A review. Aquaculture Research. 2019. https://doi.org/10.1111/are.14091.

[7] Bravo CM, Angulo LM, González YA, Martínez MM, Carmona JC, Garay OV. Evaluación reproductiva de la lombriz roja californiana (Eisenia foetida) alimentada con diferentes sustratos en el trópico bajo colombiano. Livestock Research for Rural Development, 30(2), 2018. https://www.lrrd.cipav.org.co/lrrd30/2/over30036.html

[8] Alcívar-Cedeño U, Dueñas-Rivadeneira A, Sacon-Vera E, Bravo-Sánchez L, Villanueva-Ramos G. Influencia de los tipos de secado para la obtención de harina de Lombriz Roja californiana (Eisenia foetida) a escala piloto. Tecnología Química, 36(2), 187-196, 2016. https://www.redalyc.org/comocitar.oa?id=445546335007

[9] Pires MB. Harina de lombriz: una alternativa saludable para nuestra alimentación. Universidad FASTA, Facultad de Ciencias Médicas. Licenciatura en Nutrición. 2013. http://redi.ufasta.edu.ar:8080/xmlui/handle/123456789/299.

[10] Durán L, Henríquez C. Crecimiento y reproducción de la lombriz roja (Eisenia foetida) en cinco sustratos orgánicos. Agronomía Costarricense, 33(2), 275-281, 2009. https://www.redalyc.org/html/436/43613279011/

[11] Vodounnou DS, Kpogue DN, Apollinaire MG, Didier FE. Culture of earthworm (Eisenia foetida), production, nutritive value and utilization of its meal in diet for Parachanna obscura fingerlings reared in captivity. International Journal of Fisheries and Aquatic Studies, 4(5), 01-05, 2016a.

[12] Zhenjun S, Xianchun L, Lihui S, \& Chunyang S. Earthworm as a potential protein resource. Ecology of Food and Nutrition, 36(2-4), 221-236, 1997. https://doi.org/10.1080/03670244.1997.9991517.

[13] Dynes RA. Earthworms: technology information to enable the development of earthworm production. In: Dynes, R.A., editor/s. Canberra: Rural Industries Research and Development Corporation. 2003. http://hdl.handle.net/102.100.100/190414?index $=1$

[14] Bahadori Z, Esmaielzadeh L, Karimi-Torshizi MA, Seidavi A, Olivares J, Rojas S. The effect of earthworm (Eisenia foetida) meal with vermi-humus on growth performance, hematology, immunity, intestinal microbiota, carcass characteristics, and meat quality of broiler chickens. Livestock Science, 202, 74-81, 2017. https://doi.org/10.1016/j.livsci.2017.05.010
[15] Rondón RV, Ovalles-Durán JF, León-Leal A, Medina A. Valor nutritivo de la harina de lombriz (Eisenia foetida) como fuente de aminoácidos y su estimación cuantitativa mediante cromatografía en fase reversa (HPLC) y derivatización precolumna con o-ftalaldehído (OPA). Ars Pharmaceutica, 44(1):43-58, 2003.

[16] Ferruzzi C. Manual de Lombricultura. Madrid: Ediciones Mundi Prensa. Pp. 138. 2003.

[17] Sharma K, Garg V. Management of food and vegetable processing waste spiked with buffalo waste using earthworms (Eisenia foetida). Environmental Science Pollution Resources, 24, 7829-7836, 2017. https://doi.org/10.1007/s11356-017-8438-2.

[18] Vodounnou DS, Kpogue D, Tossavi NS, Mennsah GA, Fiogbe ED. Effect of animal waste and vegetable compost on production and growth of earthworm (Eisenia foetida) during vermiculture. International Journal Recycling Organic Waste Agriculture, 5, 87-92, $2016 \mathrm{~b}$. https://doi.org/10.1007/s40093-016-0119-5

[19] Paco G, Loza-Murguía M, Mamani F, Sainz H. Efecto de la Lombriz Roja Californiana (Eisenia foetida) durante el composteo y vermicomposteo en predios de la Estación Experimental de la Unidad Académica Campesina Carmen Pampa. J Selva Andina Res Soc. 2(2),24-39, 2011. http://www.scielo.org.bo/pdf/jsars/v2n2/a04.pdf.

[20] García M, Fajardo V. Cría de la lombriz de tierra: Una alternativa ecológica y rentable. Fundación Hogares Juveniles Campesinos. Ed. San Pablo, Bogotá, Colombia. pp. 193. 2005.

[21] Schofield J, Noonan D, Chen Y, Penson P. 2014. Laboratory Animals Regulations and Recommendations for Global Collaborative Research: Australia and New Zealand. In: Laboratory Animals, 333-376. http://dx.doi.org/10.1016/B978-0-12-397856-1.00012-X

[22] Aller MA, Rodriguez J, Rodriguez G. (2020). Normas éticas para el cuidado y utilización de los animales de experimentación. Cirugía Española, 67(1), 10-13. https://www.elsevier.es/es-revista-cirugia-espanola-36-articulonormas-eticas-el-cuidado-utilizacion-8848.

[23] Hussain N, Abbasi SA. Efficacy of the vermicomposts of different organic wastes as "clean" fertilizers: State-of-the-art. Review Sustainability, 10(4), 1205, 2018. https://doi.org/10.3390/su10041205.

[24] Niamah, A. K., Sahi, A. A., \& Al-Sharifi, A. S. (2017). Effect of feeding soy milk fermented by probiotic bacteria on some blood criteria and weight of experimental animals. Probiotics and antimicrobial proteins, 9(3), 284291. https://doi.org/10.1007/s12602-017-9265-y

[25] Bou-Maroun E, Loupiae C, Loison A, Rollin B, Cayot P, Cayot N, Marquez E, Medina A. Impact of preparation process on the protein structure and on volatile compounds in Eisenia foetida protein powders. Food Nutr Sci. 2013; 4: 1175-1183, 2013. https://doi.org/10.4236/fns.2013.411151

[26] Akpodiete OJ, Okagbere GN. Feed accessories from animal production. In: Issue on Animal Sciences. A compendium of ideas, fact and methods in the science and technology of Animal Agriculture Ram Kemmedy City, Nigeria. Animal Sciences, 71-82, 1999.

[27] Medina AL, Cova JA, Vielma RA, Pujic P, Carlos MP, Torres JV. Immunological and chemical analysis of proteins from Eisenia foetida earthworm. Food and Agricultural Immunology, 15(3-4):255-263, 2003. https://doi.org/10.1080/09540100400010084.

[28] Suárez-Hernández L, Barrera-Zapata R, Forero-Sandoval A. Evaluación de alternativas de secado en el proceso de elaboración de harina de lombriz. Corpoica Cienc \& Tecnol Agropecuaria, 17(1), 55-71, 2016. https://doi.org/10.21930/rcta.vol17 num1_art:461.

[29] Castro J, Chirinos D. Nutrición Animal. tercera edición. Huancayo, Perú Gráfica José Impresores. Huancayo. Perú .265 p. 2017.

[30] Kassa A. The Different Methods of Measuring Feed Digestibility: A Review. EC Nutrition 14(1), 68-74, 2019. https://www.ecronicon.com/ecnu/pdf/ECNU-14-00542.pdf

[31] AOAC. Official Methods of Analysis of AOAC International: AOAC International, Maryland, USA, 2011.

[32] Tharel L. Total Digestible Nutrients and Protein per Acre Produced by Five Indiangrass Cultivars. Technical Report. Booneville PMC Study. Booneville, AR. CP 512 Pasture and Hay. Plant Materials Technical Report, CP 512, 2008. https://www.nrcs.usda.gov/wps/portal/nrcs/publications/plantmaterials/pm c/southeast/arpmc/pub/

[33] Stein HH, Sève B, Fuller MF, Moughan PJ, de Lange CF. Invited review: Amino acid bioavailability and digestibility in pig feed ingredients: terminology and application. J Anim Sci. 85(1), 172-180, 2007.

[34] Kassa A. The Different Methods of Measuring Feed Digestibility: A $\begin{array}{lllll}\text { Review. } & \text { EC } & \text { Nutrition } & \text { 14(1), 68-74, }\end{array}$ https://www.ecronicon.com/ecnu/pdf/ECNU-14-00542.pdf. 
[35] Crampton E, Harris L. Nutrición animal aplicada. Editorial Acribia. segunda edición Zaragoza - España. 756pp. 1974.

[36] NRC. The Nutrient Requirements of Horses, 4th revised edition. National Academy Press, Washington DC. 1978.

[37] Weiss W, Tebbe A. Estimating digestible energy values of feeds and diets and integrating those values into net energy systems, Translational Animal Science, 3(3), 953-961, 2019. https://doi.org/10.1093/tas/txy119.

[38] NRC. Nutrient Requirements of Beef Cattle: Seventh Revised Edition: Update 2000. National Academy Press, Washington DC. 2000.

[39] Galyean ML, Cole NA, Tedeschi LO, Branine ME. BOARD-INVITED REVIEW: Efficiency of converting digestible energy to metabolizable energy and reevaluation of the California Net Energy System maintenance requirements and equations for predicting dietary net energy values for beef cattle. Journal of Animal Science, vol 94, No. 4, 1329-1341, 2016. https://doi.org/10.2527/jas.2015-0223.

[40] Barakat NA, Laudadio V, Cazzato E, Tufarelli V. Potential Contribution of Retama raetam (Forssk.) Webb \& Berthel as a Forage Shrub in Sinai, Egypt. Arid Land Research and Management, 27(3), 257-271, 2013. https://doi.org/10.1080/15324982.2012.756561

[41] Sainz RD, Fernández C, Baldwin RL. Valoración de alimentos para rumiantes en cebo: el Sistema Americano NRC. X Curso de Especialización FEDNA. Madrid. 1994. http://www.ucv.ve/fileadmin/user_upload/facultad_agronomia/NRC_Bovi nos.pdf.

[42] Castro J, Chirinos D, Calderón J. Calidad nutricional del rastrojo de maca (Lepidium peruvianum Chacón) en cuyes. Rev. investig. vet. Perú, 29(2), 410-418. ISSN 1609-9117. http://dx.doi.org/10.15381/rivep.v29i2.13405.

[43] Gunya B, Masika P, Hugo A, Muchenje V. Nutrient Composition and Fatty Acid Profiles of Oven-dried and Freeze-dried Earthworm Eisenia foetida. Journal of Food and Nutrition Research, 4(6), 343-348, 2016. https://doi.org/10.12691/jfnr-4-6-1

[44] Segovia E. Obtención y caracterización de la Harina de Lombriz (Eisenia Foetida) para Consumo Animal. Tesis. Universidad Nacional Federico Villarreal. Lima. Perú. 1997.

[45] De Chaves RC, Paula RQ, Gücker B, Marriel IE, Teixeira AO, Boëchat IG. An alternative fish feed based on earthworm and fruit meals for tilapia and carp postlarvae. R. bras. Bioci., Porto Alegre, vol. 13(1), 15-24, 2015. https://www.researchgate.net/publication/307547140.

[46] Mohanta KN, Subramanian S, Korikanthimath VS. Potential of earthworm (Eisenia foetida) as dietary protein source for rohu (Labeo rohita) advanced fry. Cogent Food \& Agriculture, 2(1), 2016. https://doi.org/10.1080/23311932.2016.1138594.

[47] Wang H, Shi M, Xu X, Ma X, Liu L, Piao X. Comparative energy content and amino acid digestibility of barley obtained from diverse sources fed to growing pigs. Asian-Australas J Anim Sci. 30(7), 999-1005, 2017. https://doi.org/10.5713/ajas.16.0775

[48] Pérez-Corría K, Botello-León A, Mauro-Félix A, Rivera-Pineda F, Viana M, Cuello-Pérez M, Botello-Rodríguez A, Martínez-Aguilar Y. Chemical Composition of Earthworm (Eisenia foetida) Co-Dried with Vegetable Meals as an Animal Feed. Ciencia y Agricultura, 16(2),79-92, 2019. https://doi.org/10.19053/01228420.v16.n2.2019.9130 